\title{
Does Delaware Incorporation Encourage Effective Monitoring? An Examination on Director Compensation
}

\author{
Qian Xie ${ }^{1,2}$ \\ ${ }^{1}$ School of Business and Management, East Stroudsburg University of Pennsylvania, USA \\ ${ }^{2}$ School of Business, Southern Illinois University Carbondale, USA \\ Correspondence: Qian Xie, School of Business and Management, East Stroudsburg University of Pennsylvania, USA. \\ Tel: 1-618-201-9300. E-mail: qxie@esu.edu
}

Received: August 7, 2013

doi:10.5430/ijfr.v4n4p26

\author{
Accepted: September 1, 2013 \\ Online Published: October 8, 2013 \\ URL: http://dx.doi.org/10.5430/ijfr.v4n4p26
}

\begin{abstract}
Delaware incorporation is popular among publicly traded firms in the United States. However, the question of whether Delaware incorporation favors shareholders is an on-going debate. This paper is the first attempt to examine director compensation by considering the role of state of incorporation. First, Delaware firms pay their directors more compensation than non-Delaware firms. Second, Delaware firms tend to hold more meetings per year than non-Delaware firms. Finally, among Delaware firms, the changes of director cash compensation, equity compensation, and total compensation are positively related to the change of shareholder wealth. The results not only indicate that Delaware incorporation appears to encourage effective board monitoring but also support the view of "race to the top" on Delaware incorporation.
\end{abstract}

Keywords: Delaware incorporation, director compensation, pay-performance sensitivity, board meeting frequency, state corporate laws, corporate governance

\section{Introduction}

U.S. firms are governed by their state of incorporation, not by the location of their headquarters or where they conduct their business. Each state in the United States has a different set of corporate laws and competes with other states to attract firms to incorporate in its own state. By selecting a state of incorporation, a firm selects a set of laws under which it must operate. Clark (1985) indicates that legal systems impact corporate governance because regulations may be an additional monitoring and control mechanism. Sound legal systems are more important for firms that operate in an environment with relatively poor investor protection because it leads to greater expropriation by managers at the expenses of shareholders. Under heavy regulations, firms may be more stable and agency problem is less intense.

A study by Choi, Kamma, and Weintrop (1989) finds that more than fifty percent of the firms listed on the New York Stock Exchange and American Stock Exchange are incorporated in Delaware even though the state of Delaware charges higher formation and annual fees than most other states do. The dominance of incorporation and reincorporation in the state of Delaware has remained stable over the last four decades (Subramanian, 2002). Two theories have evolved from the debate about the popularity of Delaware incorporation among publicly traded companies. The theory of "race to the bottom" suggests that state incorporation competition caters to the needs of managers (Cary, 1974). In other words, Delaware incorporation favors managers at the expense of shareholders. The other theory, "race to the top", indicates that Delaware incorporation favors shareholders. Several studies support "race to the top" in that firms incorporated in Delaware have better board structure (Jiraporn, Chintrakarn, \&Davidson , 2009 ), fewer occurrences of earnings management (Jiraporn \& Gleason; 2007), and more forced CEO turnovers (Jagannathan, Paul, \& Pritchard; 2007).

Directors act as an intermediary between shareholders and managers. Shareholders elect directors to represent them and to monitor and evaluate top management members who have incentives and opportunities to pursue maximization of their own interests. Clark (1985) contends that under U.S. laws, directors are the ultimate decision-making body of the corporation and are fiduciaries with respect to the corporation and its stockholders. However the recent surge in corporate scandals has put pressure on directors to focus on governance. Boards now 
face criticism for failing to protect shareholders' interests. The passage of Sarbanes-Oxley Act has introduced new accountabilities on boards of directors. This act stipulates that directors can be fined or even have prison sentences for being ineffective monitors and involved in accounting frauds. There has been widely-spread interest in the research on the board of directors for decades (Hermalin \& Weisbach, 1998; John \& Senbet, 1998). Factors such as board size, independence, diversity, ownership, etc. may impact the effectiveness of a board's monitoring role (John \& Senbet, 1998). Director compensation, an area receiving little scrutiny in the board literature, is also important because the board of directors needs incentives to better perform its monitoring role. With no stakes in the firm, directors may have no incentives to protect shareholders' interests. According to Adams and Ferreira (2008), the more directors get paid, the more willingly they attend board meetings, a measure of intensity of director monitoring. Previous research on director compensation mainly focused on big publicly traded firms and did not consider the impact of different state corporate laws. In this study, Delaware incorporation presents a unique situation to test the influence of corporate laws that may encourage directors to monitor the CEO to align the agency conflict between the CEO and shareholders.

If Delaware incorporation favors shareholders, it is expected that directors in firms that are incorporated in Delaware are more financially motivated to monitor CEOs. This paper is the first attempt to examine director compensation and the pay-performance sensitivity of director compensation to shareholder wealth by considering the role of state of incorporation. By using a sample of 628 Delaware firms and 423 non-Delaware firms from 2002 to 2009 in ExecuComp, I first find the evidence of the dominance of incorporation in the state of Delaware among publicly traded firms. Second, Delaware firms pay their directors more compensation than non-Delaware firms do. Third, Delaware firms tend to hold more meetings per year than non-Delaware firms do, a results showing active monitoring role of directors. Finally, a positive and significant relation between the change of director compensation and the change of shareholder wealth in Delaware firms suggests Delaware incorporation does benefit shareholders. The findings in this paper support "race to the top" (Winter, 1977) on Delaware incorporation. The results of this paper may be helpful for firms that must choose a state to be incorporated or reincorporated. Delaware incorporation sends positive signals to shareholders who care about the quality of corporate governance.

The rest of this paper is organized as follows: Section 2 provides a brief literature review about Delaware incorporation and director compensation, as well as hypotheses. Section 3 describes data sources, sample selection, and variables definitions. In Section 4 I discuss the empirical results and their implications in details. Finally, Section 5 summarizes this study.

\section{Literature Review and Hypotheses}

\subsection{Director Compensation}

The need for directors to monitor the CEO has increased substantially in the wake of recent corporate scandals. With the passage of the Sarbanes-Oxley Act, the role of the board has become more complex and time-consuming than before because the board has to take more duties and responsibilities. To meet the requirements by the Sarbanes-Oxley Act, companies need to recruit and retain independent and qualified directors. Therefore, granting more compensation to directors may be more necessary after the Act.

Although the amount of compensation granted to directors is far less than that to CEOs, directors do perform even for very small amount of board meeting fees (Adams \& Ferreira, 2008). The more directors get paid, the more willingly directors attend board meetings. According to the National Association of Corporate Directors, the average fee paid to directors at the largest 200 companies in the nation was $\$ 156,000$, an amount enough to influence a person's judgment (Murphy \& Zabojnik, 2004). Spatt (2005) discovers that board members are often disengaged because of low compensation.

The use of higher compensation, especially incentive compensation, improves directors' willingness to monitor CEOs (Hermalin \& Weisbach, 1998; Gillette, Noe, \& Rebello, 2003) and therefore increases firm performance (Fich \& Shivdasani, 2005; Benito \& Conyon, 1999). Perry (2000) also shows the likelihood of CEO turnover following poor performance increases when directors receive incentive compensation. Therefore, granting higher compensation to directors is an important incentive for strong corporate governance.

\subsection{Hypothesis Development}

The theory of "race to the top" (Winter, 1977) about Delaware Incorporation suggests that the market will discipline managers if they choose to incorporate in a state whose laws favor managers. Daines (2001) shows a positive relation between Delaware incorporation and a higher Tobin's Q. He further explains that by incorporating in Delaware, firms prohibit managers from gaining political influence with lawmakers. In addition, Delaware has sufficient 
expertise and specialized judiciary that may increase shareholders' value. The theory indicates that Delaware incorporation favors shareholders, not managers.

Like the laws and regulations at country level, state corporate laws may make difference in corporate governance as well. Jiraporn, Chintrakarn, and Davidson (2009) find that the boards of Delaware firms are relatively more independent and smaller than those of non-Delaware firms. Although Delaware corporate laws affect the effectiveness of internal corporate governance, after the passage of the Sarbanes-Oxley Act, the positive impact of Delaware law on board structure and firm value disappears. This disappearance indicates that corporate laws at the country level or the state level can substitute with each other. Jiraporn and Gleason (2007) find that earnings management occurs less in Delaware firms than in non-Delaware firms. Jagannathan, Paul, and Pritchard (2007) find that Delaware firms have a significantly higher rate of forced turnover for their CEOs. CEOs with poor performance in Delaware are more likely to be terminated than those in other states. They further argue that the reason for this higher CEO turnover in Delaware firms is that Delaware is capable of attracting highly qualified executives from other states. These studies have shown that Delaware firms have better corporate governance mechanisms to align the agency conflicts between shareholders and management.

If state corporate laws in Delaware favor shareholders, these firms incorporated in Delaware may pay their directors more compensation to encourage them to better monitor CEOs than non-Delaware firms do. Therefore, I hypothesize as follows:

Hypothesis 1: Delaware firms pay their directors with higher compensation than non-Delaware firms do.

Firms that require more monitoring are more likely to have a greater number of board meetings. Prior research has identified the relations among board meetings, compensation, and firm performance. Vafeas (1999) finds that board meeting frequency increases after firm performance increases. Brick, Palmon, \& Wald (2006) find that CEOs receive higher cash compensation but less incentive-based compensation in firms that have fewer board meetings. Because meeting frequency is considered as a measure of intensity of director monitoring, a firm with more frequent board meetings provides directors more opportunities to learn about the firm's operation, strategies, and performance. Furthermore, more frequent board meetings indicate less information asymmetry and more interactions between board members and managers. Adams and Ferreira (2008) suggest a signaling theory, which argues that firms may offer directors more meeting fees to signal that they value board meeting attendance. If Delaware corporate laws result in better corporate governance, meeting frequency may be higher among Delaware firms. Studies (Weisbach, 1988; Byrd \& Hickman, 1992; Brickley, Coles, \& Terry, 1994; Borokhovich, Parrino, \& Trapani, 1996; and Cotter, Shivdasani, \& Zenner, 1997) have documented the monitoring role of outside directors. If higher board activity facilitates better board monitoring, outside directors are likely to demand more board meetings to enhance their abilities to monitor management. Lipton and Larsch (1992) point out that one of the criticisms that boards face is that boards do not spend enough time to work for the companies. So if Delaware incorporation favors shareholders, effective director monitoring may be reflected in the high frequency of board meetings. Therefore, we hypothesize as follows:

Hypothesis 2: Meeting frequency is higher in Delaware firms than in non-Delaware firms.

If Delaware corporate laws are better than the corporate laws in other states, shareholders in Delaware firms will benefit from Delaware incorporation. In other words, Delaware firms do not favor managers at the expense of shareholders. It is thus expected that, in Delaware firms, management does not becomes entrenched and directors can effectively monitor the management. Furthermore, the conflict between shareholders and directors is less intense in Delaware firms. Executive pay-performance sensitivity has been used as one of indicators or the quality of corporate governance. Thus, director pay-performance sensitivity is used to test the third hypothesis:

Hypothesis 3: In Delaware firms, change of director compensation is positively related to change of market value.

\section{Sample}

ExecuComp provides director compensation data, which include annual cash retainer, the number of board meetings per year, the fee paid to director per board meeting, the number of shares of stock, and the number of options to directors. The information about the state of incorporation is gathered from the filing headers of proxy statements from EDGAR. Accounting measures are from the Compustat.

The sample of the firms in this study is S\&P 1500 companies as listed in the Compustat. The S\&P 1500 includes the stocks of 500 large-cap corporations, 400 mid-cap corporations, and 600 small-cap corporations. I exclude financial companies and utility companies from the list because these two industries are under extensive regulations. Among the firms in the S\&P 1500 list, firms that incorporate in other countries are also excluded. In order to examine the 
incorporation effect, firms that have incorporated in the state of Delaware or other states less than eight years are also excluded from the sample. The final sample includes 1051 firms. There are 628 firms incorporated in the state of Delaware and 423 firms incorporated in other states. The sample period spans from 2002 to 2009.

\section{Results}

4.1 Delaware Incorporation

Table 1. State incorporation

\begin{tabular}{lll}
\hline & Numbers & Percentage \\
\hline Delaware Firms & 628 & $60 \%$ \\
Non-Delaware Firms & 423 & $40 \%$ \\
\hline Total Firms & 1051 & $100 \%$
\end{tabular}

Among the sample of 1057 firms, 628 firms chose to incorporate in the state of Delaware and 423 firms chose to incorporate in other states. In other words, about $60 \%$ of the firms in the sample are incorporated in Delaware, an evidence that matches the results found by Choi, Kamma, and Weintrop (1989) and Subramanian (2002). In the study of Choi et al. (1989), more than 50 percent of the firms listed on the New York and American stock exchanges are incorporated in Delaware.

\subsection{Combinations of Director Compensation}

Table 2. Compensation combinations in Delaware and non-Delaware firms

\begin{tabular}{lllll}
\hline $\begin{array}{l}\text { Compensation } \\
\text { combinations }\end{array}$ & Delaware Firms & Percentage & $\begin{array}{l}\text { Non-Delaware } \\
\text { firms }\end{array}$ & Percentage \\
\hline 1. a & 16 & $2.55 \%$ & 16 & $3.78 \%$ \\
2. ab & 42 & $6.69 \%$ & 36 & $8.51 \%$ \\
3. abc & 110 & $17.52 \%$ & 80 & $18.91 \%$ \\
4. abcd & 75 & $11.94 \%$ & 54 & $12.77 \%$ \\
5. abd & 194 & $30.89 \%$ & 119 & $28.13 \%$ \\
6. acd & 37 & $5.89 \%$ & 27 & $6.38 \%$ \\
7. ac & 53 & $8.44 \%$ & 31 & $7.33 \%$ \\
8. ad & 59 & $9.39 \%$ & 36 & $8.51 \%$ \\
9. b & 2 & $0.32 \%$ & 4 & $0.95 \%$ \\
10. bc & 7 & $1.11 \%$ & 3 & $0.71 \%$ \\
11. bcd & 6 & $0.96 \%$ & 3 & $0.71 \%$ \\
12. bd & 8 & $1.27 \%$ & 4 & $0.95 \%$ \\
13. c & 4 & $0.64 \%$ & 0 & 0 \\
14. cd & 6 & $0.96 \%$ & 3 & $0.17 \%$ \\
15. d & 9 & $1.43 \%$ & 7 & $1.65 \%$ \\
\hline Total & 628 & $100 \%$ & 423 & $100 \%$ \\
\hline
\end{tabular}

a: annual retainer b: meeting fee c: stocks d: options

Annual retainers, meeting fees, stocks, and options are four basic payment forms for directors. In the sample of 628 Delaware firms, 41 firms do not offer an annual retainer to their directors and 184 firms do not compensate directors for director meetings. Surprisingly, 330 Delaware firms do not provide stocks for their directors. However, 394 out of 628 Delaware firms do offer options to directors. Options seem to be slightly more popular than stocks in Delaware firms. Similar results can be found in the sample of non-Delaware firms.

Table 2 shows various compensation combinations in Delaware and non-Delaware firms. There are totally fifteen combinations of director compensation. They are: 1) an annual retainer only, 2) an annual retainer and meeting fees only, 3) an annual retainer, meeting fees, and stocks, 4) an annual retainer, meeting fees, stocks, and options, 5) an 
annual retainer, meeting fees, and options, 6) an annual retainer, stocks, and options, 7) an annual retainer and stocks, 8) an annual retainer and options, 9) meeting fees only, 10) meeting fees and stocks, 11) meeting fees, stocks, and options, 12) meeting fees and options, 13) stocks only, 14) stocks and options, and 15) options only.

In both the Delaware sample and non-Delaware sample, combination 3, combination 4, and combination 5 are more popular than the rest of the combinations. About $60 \%$ of Delaware and non-Delaware firms choose one of the above three combinations as director compensation. The three combinations all have an annual retainer and meeting fees. The most popular combination is combination 5, which has an annual retainer, meeting fees, and options. More than $30 \%$ of Delaware firms choose combination 5. For non-Delaware firms, the number is $28.13 \%$. The second most popular payment method is combination 3, which includes an annual retainer, meeting fees, and stocks. More firms prefer options to stocks. The least popular payment method in Delaware firms is combination 9 (meeting fees only). The least popular payment method in non-Delaware firms is combination 13 (stocks only).

\subsection{Descriptive Statistics}

\subsubsection{Director Compensation}

Descriptive statistics of director compensation in Delaware firms and non-Delaware firms are presented in Table 3. Total director compensation is the total sum of the annual retainer, meeting fee multiplied by number of meetings, value of stocks, and the Black-Scholes value of the options. Total compensation is divided into cash compensation and equity compensation. Cash compensation is equal to the sum of the annual retainer and total meeting fees. Equity compensation includes stock and option values. To calculate the Black-Scholes value of options, I follow the assumptions of Yermack (2004) that the exercise price is equal to the average stock price during the grant year and time to maturity is 10 years. When I test the director pay-performance sensitivity, I use the change in director compensation. I examine each component of director compensation because every component of director compensation has its own benefits and drawbacks to motivate directors to monitor management and act in the interest of shareholders. I adjust all the nominal compensation data using annual CPI data for the United States Bureau of Labor Statistics (stats.bls.gov).

From 2002 to 2009, Delaware firms paid their directors $\$ 32,540$ as an annual retainer and non-Delaware firms paid $\$ 28,780$. Delaware firms held 7.80 annual meetings per year, which is higher than non-Delaware firms. Delaware firms granted more options and paid more total meeting fees, stock compensation, option compensation, total equity compensation, and total compensation to their directors. The significant results show that Delaware firms generally paid their directors more compensation, either cash or equity, than non-Delaware firms did.

\subsubsection{Firm Performance and Characteristics}

I use both accounting and market values as firm performance measures (Yermack, 1996; Perfect \& Wiles, 1994). Accounting and market based measures of firm performance both have weaknesses. Accounting measures may be subject to management manipulation while market-based measures are sensitive to factors beyond management control. Return on assets (ROA) captures a firm's operating profits over the most recent fiscal year. Tobin's Q is the ratio of the market value of the firm to the replacement value of total assets. Market value is the book value of debt and preferred stock plus market value of common stock. Replacement value of assets is the total book value of assets. To capture pay-performance sensitivity, change of shareholder wealth is also used (Jensen \& Murphy, 1999a). Firm size is the logarithm of a firm's total assets. Large firms usually have more complex operation structure and require more direct monitoring. Therefore firm size may impact the amount of director compensation. Firm's risk is measured as the standard deviation of the security market returns. For risk-averse directors, compensation may increase as their compensation risk aligns with firm risk. Therefore firm risk may be a potential determinant of director compensation. Investment opportunity is defined as R\&D expenditures scaled by sales prior to the year in which director compensation is paid. R\&D signals a firm's potential to generate future investment. Leverage is measured as long term debt divided by total assets. Brick et al. (2006) find that leverage is significantly related to outside director equity compensation. Dividends play an important role of monitoring because it is expected that firms distribute dividends in order to induce external monitoring and to prevent overinvestment by managers. Jensen (1986) also claims that dividends may control overinvestment problems and reduce the agency cost. The ratio of dividend to assets is used to explain payout policy (Fama \& French, 2002). Expense ratio is used to test the role of directors in controlling agency cost. 
Table 3. Descriptive statistics of director compensation and other firm variables between Delaware and non-Delaware firms (2002-2009)

\begin{tabular}{llllll}
\hline & Delaware & \multicolumn{3}{l}{ non-Delaware } \\
\hline variables & Mean & SD & Mean & SD & t-statistic \\
\hline Retainer & 32.54 & 19.15 & 28.78 & 18.66 & $5.57^{* * *}$ \\
Meeting fee per meeting & 1.24 & 1.04 & 1.27 & 1.05 & -0.95 \\
Number of meetings & 7.80 & 3.24 & 7.22 & 3.12 & $2.62^{* * *}$ \\
Total meeting fees & 10.48 & 9.18 & 9.71 & 8.56 & $2.71^{* * *}$ \\
Stock compensation & 27.58 & 52.76 & 25.47 & 26.33 & $8.82^{* * *}$ \\
Option compensation & 143.92 & 239.24 & 109.31 & 295.54 & $3.70^{* * *}$ \\
Total equity comp & 138.33 & 259.16 & 110.52 & 307.95 & $6.59^{* * *}$ \\
Total compensation & 203.32 & 237.14 & 166.25 & 286.73 & $5.77^{* * *}$ \\
Firm size & 9984.83 & 43273.11 & 8136.72 & 41002.88 & $5.92^{* * *}$ \\
Free cash & 0.0002 & 0.13 & 0.0003 & 0.11 & -0.45 \\
Risk & 0.49 & 0.25 & 0.44 & 0.17 & $4.12^{* * *}$ \\
Investment opportunity & 0.10 & 0.12 & 0.08 & 0.21 & 1.48 \\
Expense & 0.28 & 0.20 & 0.24 & 0.18 & $1.91^{*}$ \\
Dividend & 0.002 & 0.02 & 0.001 & 0.04 & $3.50^{* * *}$ \\
Leverage & 0.19 & 0.16 & 0.17 & 0.14 & 0.34 \\
Tobin's Q & 2.10 & 1.22 & 1.98 & 1.07 & $3.19^{* * *}$ \\
ROA & 4.63 & 10.17 & 4.99 & 10.36 & -0.98 \\
\hline
\end{tabular}

$* * *, * *$, and $*$ denote significance levels of $1 \%, 5 \%$, and $10 \%$.

Table 3 also presents summary statistics on firm characteristics. The average firm size of Delaware firms is $\$ 9,984.83$ million. The average firm size of non-Delaware firms is $\$ 8,136.72$ million. The significant mean difference shows that, on average, Delaware firms are bigger than non-Delaware firms. This result may be one of the reasons for the previous finding that all components of director compensation in Delaware firms are higher than those in non-Delaware firms. The mean differences of free cash ratio, investment opportunity, leverage ratio, and ROA are insignificant between Delaware firms and non-Delaware firms. On average, Delaware firms are riskier than non-Delaware firms. Expense ratio and dividend ratio are higher in Delaware firms. Finally, the value of Tobin's Q among Delaware firms, 2.10, is higher than that among non-Delaware firms, 1.98 .

\subsection{Regression Analysis}

To test the first hypothesis that Delaware firms are more likely to pay their directors with higher compensation than non-Delaware firms, the following model is implemented:

Director Compensation $=f$ (Delaware dummy, firm performance and characteristics variables, and year dummy variables)

The dependent variable of director compensation is the log value of each component of director compensation. The following components of director compensation are tested individually: total director compensation, cashed-based compensation, annual retainer, total meeting fees, equity compensation, stocks, and options. Total director compensation includes an annual retainer, meeting fee, stocks, options, and the others. Cash compensation includes an annual retainer and meeting fees. Equity compensation consists of stocks and options. Another two dummy dependent variables, stock dummy and option dummy, are also included. Delaware is a dummy variable, which equals to 1 if a firm is incorporated in Delaware, otherwise 0. Other independent variables are ROA, Tobin's Q, firm size, free cash ratio, risk, investment opportunity, expense ratio, dividend ratio, and leverage. 


\subsubsection{Cash Director Compensation and Delaware Incorporation}

Table 4. Determinants of each of cash components of director compensation between Delaware and non-Delaware firms

\begin{tabular}{|c|c|c|c|}
\hline & 1 & 2 & 3 \\
\hline & Retainer & Total Meeting Fees & Cash Compensation \\
\hline Constant & $0.532 * * *(21.423)$ & $1.661 * * *(14.746)$ & $2.735 * * *(27.323)$ \\
\hline Delaware & $0.045^{* * *}(3.336)$ & $0.042(1.459)$ & $0.075 * * *(2.771)$ \\
\hline Firm size & $0.664 * * *(20.673)$ & $0.358 * * *(6.672)$ & $0.457 * * *(17.834)$ \\
\hline Free cash & $0.044(0.362)$ & $-0.107(-0.884)$ & $0.102(1.503)$ \\
\hline Risk & $-0.083(-1.117)$ & $0.120 * * *(3.205)$ & $0.013(0.607)$ \\
\hline Invest. Opp. & $-0.106^{* * *}(-4.573)$ & $0.002(0.020)$ & $-0.095 * * *(-2.472)$ \\
\hline Expense & $0.116^{* *}(2.374)$ & $0.104 * *(2.011)$ & $0.108 * * *(2.634)$ \\
\hline Dividend & $0.059(1.487)$ & $0.009(0.428)$ & $0.002(0.053)$ \\
\hline Leverage & $0.023(0.804)$ & $-0.035(-0.801)$ & $0.019(0.451)$ \\
\hline Tobin's Q & $-0.108 * *(-2.538)$ & $-0.017(-0.436)$ & $-0.050 * *(-2.269)$ \\
\hline $\mathrm{ROA}$ & $0.061(1.626)$ & $0.047(0.481)$ & $0.067(1.145)$ \\
\hline F-statistics & $80.735^{* * *}$ & $8.769 * * *$ & $52.637 * * *$ \\
\hline $\begin{array}{l}\text { Adjusted R } \\
\text { square }\end{array}$ & $29.6 \%$ & $6.7 \%$ & $23.9 \%$ \\
\hline
\end{tabular}

Results of year dummy variables are not reported here. ***, **, and * denote significance levels of $1 \%, 5 \%$, and $10 \%$. T-statistics are in parentheses.

In the first regression, the dependent variable is annual retainer. The estimated coefficient of Delaware is positive (0.045) and significant, indicating that Delaware firms pay directors a higher annual retainer. A positive and significant estimated coefficient of firm size suggests that larger firms pay more annual retainers to their directors. The two estimated coefficients of investment opportunity and Tobin's Q are significantly negative. Therefore, firms with more potential of growth do not pay more annual retainers to their directors. If firms occur more expenses such as administrative or selling expenses, these firms pay more annual retainers.

The second regression, total meeting fees are equal to meeting fee per meeting times total number of meetings per year. The estimated coefficient of Delaware in this regression is insignificant. However, the estimated coefficients of firm size, risk, and expense ratio are all significantly positive. Firms with larger size, higher risk, and higher expense ratios pay more total meeting fees.

The estimated coefficient of Delaware in the third regression is positive (0.075) and significant. If a firm is incorporated in Delaware, the firm pays higher cash-based compensation to its directors than a non-Delaware firm does. Total cash compensation is positively and significantly related to firm size and expense ratio but negatively and significantly related to investment opportunity and Tobin's Q. 


\subsubsection{Equity Compensation and Delaware Incorporation}

Table 5. Determinants of each of equity components of director compensation between Delaware and non-Delaware firms

\begin{tabular}{llll}
\hline & \multicolumn{1}{c}{1} & \multicolumn{1}{c}{2} & \multicolumn{1}{c}{3} \\
& Stock Compensation & Option Compensation & Total Equity Compensation \\
Constant & $1.672^{* * *}(6.548)$ & $2.168^{* * *}(10.521)$ & $2.759^{* * *}(13.267)$ \\
Delaware & $0.364^{* * *}(4.689)$ & $0.283^{* * *}(5.349)$ & $0.152^{* * *}(5.936)$ \\
Firm size & $0.386^{* * *}(6.517)$ & $0.152^{* * *}(4.261)$ & $0.268^{* * *}(6.663)$ \\
Free cash & $0.061(0.455)$ & $-0.084(-1.126)$ & $-0.066(-0.883)$ \\
Risk & $0.059(1.396)$ & $0.233^{* * *}(7.882)$ & $0.147^{* * *}(5.694)$ \\
Invest. Opp. & $0.028(0.504)$ & $0.192^{* * *}(4.359)$ & $0.179^{* * *}(4.667)$ \\
Expense & $0.059(1.302)$ & $0.117^{* *}(2.473)$ & $0.174^{* * *}(3.595)$ \\
Dividend & $-0.106^{* *}(-2.085)$ & $-0.211^{* * *}(-7.746)$ & $-0.202^{* * *}(-7.465)$ \\
Leverage & $0.015(0.009)$ & $-0.129^{* * *}(-4.535)$ & $-0.135^{* * *}(-4.774)$ \\
Tobin's Q & $0.142^{* * *(2.633)}$ & $0.287^{* * *}(10.725)$ & $0.275^{* * *}(10.082)$ \\
ROA & $-0.059(-0.453)$ & $0.183^{* * *}(2.622)$ & $0.152^{* *}(2.158)$ \\
& & & \\
F-statistics & $15.735^{* * *}$ & $62.617^{* * *}$ & $58.361^{* * *}$ \\
Adjusted R & $25.8 \%$ & $37.6 \%$ & $33.7 \%$ \\
square & & &
\end{tabular}

Results of year dummy variables are not reported here. ${ }^{* * *}, * *$, and $*$ denote significance levels of $1 \%, 5 \%$, and $10 \%$. $\mathrm{T}$-statistics are in parentheses.

Directors are granted equity compensation by firms to tie the firms' performance to directors' performance. The increased use of equities as a part of director compensation has gain more popularity in recent years. Table 5 tests the relation between Delaware incorporation and each component of equity compensation. The estimated coefficient of Delaware in Regression 1 is 0.364 and significant at $1 \%$. A Delaware firm pays more stock compensation to its directors than a non-Delaware firm. A Large firm also pays more stock compensation. The result of Tobin's Q indicates that if a firm has more growth opportunity, it pays more stock compensation as well. However, if a firm pays more dividends to shareholders, it pays less stock compensation.

In the second regression, the estimated coefficient of Delaware is positive and significant again, suggesting that Delaware firms pay more option compensation to directors. Other determinants such as firm size, risk, investment opportunity, expense ratio, dividend, leverage, Tobin's Q, and ROA are all related to the amount of option compensation paid to directors. If a firm is larger, riskier, and has less debt but more growth and investment opportunities, the firm pays more option compensation.

The dependent variable in the third regression is total equity compensation. The estimated coefficient of Delaware is 0.152 and significant at $1 \%$. The result indicates that Delaware firms pay more equity compensation. Like the results in the second regression for option compensation. A firm pays more total equity compensation if the firm is larger, riskier, and has less debt but more growth and investment opportunities. 
4.4.3 Total Director Compensation, Number of Meetings, Granting Equities, and Delaware Incorporation

Table 6. Determinants of total director compensation, stock dummy variable, option dummy

\begin{tabular}{|c|c|c|c|c|}
\hline & 1 & 2 & 3 & 4 \\
\hline $\begin{array}{l}\text { Dependent } \\
\text { variable }\end{array}$ & $\begin{array}{l}\text { Total director } \\
\text { compensation }\end{array}$ & $\begin{array}{l}\text { Number of } \\
\text { meetings }\end{array}$ & $\begin{array}{l}\text { Stock } \\
\text { dummy }\end{array}$ & $\begin{array}{l}\text { Option } \\
\text { dummy }\end{array}$ \\
\hline \multirow[t]{2}{*}{ Constant } & $3.240 * * *$ & $1.872 * * *$ & -3.958 & 2.735 \\
\hline & (16.313) & $(24.852)$ & $(0.527)$ & $(0.428)$ \\
\hline \multirow[t]{2}{*}{ Delaware } & $0.128 * * *$ & $0.104 * * *$ & -2.738 & 0.302 \\
\hline & $(4.527)$ & $(3.581)$ & $(0.137)$ & $(0.125)$ \\
\hline \multirow[t]{2}{*}{ Firm size } & $0.336 * * *$ & $0.135 * * *$ & 0.404 & -0.211 \\
\hline & $(9.362)$ & $(6.459)$ & $(0.052)$ & $(0.063)$ \\
\hline \multirow[t]{2}{*}{ Free cash } & 0.086 & $0.142 * *$ & 1.376 & -2.132 \\
\hline & $(1.037)$ & $(2.630)$ & (1.046) & $(1.271)$ \\
\hline \multirow[t]{2}{*}{ Risk } & $0.183 * * *$ & 0.062 & -0.369 & 0.359 \\
\hline & $(7.117)$ & $(0.538)$ & $(0.224)$ & $(0.358)$ \\
\hline \multirow[t]{2}{*}{ Invest. Opp. } & $0.216 * * *$ & -0.023 & -5.247 & 6.359 \\
\hline & $(5.537)$ & $(-1.041)$ & $(1.210)$ & (1.005) \\
\hline \multirow[t]{2}{*}{ Expense } & $0.108 * *$ & $0.183 * * *$ & 1.746 & 0.225 \\
\hline & $(3.244)$ & $(3.946)$ & $(0.407)$ & $(0.371)$ \\
\hline \multirow[t]{2}{*}{ Dividend } & $-0.190 * * *$ & 0.017 & $12.647 * * *$ & $-7.523 * * *$ \\
\hline & $(-5.348)$ & $(0.316)$ & $(4.256)$ & $(4.682)$ \\
\hline \multirow[t]{2}{*}{ Leverage } & $-0.059 * * *$ & -0.019 & 0.626 & -0.522 \\
\hline & $(-3.312)$ & $(-0.433)$ & $(0.405)$ & $(0.483)$ \\
\hline \multirow[t]{2}{*}{ Tobin’s Q } & $0.371 * * *$ & $-0.117 * * *$ & -0.208 & 0.072 \\
\hline & $(9.638)$ & $(-3.142)$ & $(0.070)$ & $(0.050)$ \\
\hline \multirow[t]{2}{*}{ ROA } & $0.472 * * *$ & $-0.151 * * *$ & -0.022 & 0.047 \\
\hline & $(3.930)$ & $(-3.992)$ & $(0.072)$ & $(0.055)$ \\
\hline F-statistics & $50.167 * * *$ & $11.565^{* * *}$ & log likelihood & log likelihood \\
\hline \multirow{3}{*}{$\begin{array}{l}\text { Adjusted R } \\
\text { square }\end{array}$} & $23.6 \%$ & $7.0 \%$ & 1736.157 & 1525.116 \\
\hline & & & chi-square & chi-square \\
\hline & & & $356.130 * * *$ & $155.392 * * *$ \\
\hline
\end{tabular}

Results of year dummy variables are not reported here. ${ }^{* *}, * *$, and $*$ denote significance levels of $1 \%, 5 \%$, and $10 \%$. T-statistics are in parentheses.

Total director compensation includes an annual retainer, meeting fees, stocks, options, and the others. The estimated coefficient of Delaware in the first regression in Table 6 is 0.128 and significant at 1\%, indicating that Delaware firms pay more total compensation to their directors than non-Delaware firms do. Firms with larger size, more risk, more investment/growth opportunities, and more expenses generally pay their directors more total compensation.

In the second regression, the significantly positive estimated coefficient of Delaware shows that Delaware firms hold more annual meetings per year. Furthermore, if a firm is larger, riskier, has more free cash or expenses, and has growth problems, the board in this firm tends to hold more meetings per year.

The insignificant estimated coefficient of Delaware dummy variable in Regressions 3 and 4 shows that has no relation about whether a firm is incorporated in Delaware and whether the firm grants stocks or options to its directors.

In summary, a Delaware firm generally pays its directors more annual retainer, cash compensation, stock compensation, option compensation, equity compensation, and total compensation than a non-Delaware firm does. In addition, a Delaware firm tends to hold more meetings per year than a non-Delaware firm. However, being incorporated in Delaware does not make a firm more likely to grant stocks or options to its directors. 
4.4.4 Pay-Performance Sensitivity between Delaware Firms and Non-Delaware Firms

To test the second hypothesis about pay-performance sensitivity in Delaware and non-Delaware firms, the method in Jensen and Murphy (1990a and 1990b) is used:

Change of Director Compensation $=f$ (Change of market value, and control variables)

Table 7. Pay-performance sensitivity of cash compensation between Delaware and non-Delaware firms

\begin{tabular}{|c|c|c|c|c|c|c|}
\hline & \multicolumn{3}{|c|}{ Delaware firms } & \multicolumn{3}{|c|}{ Non-Delaware firms } \\
\hline & 1 & 2 & 3 & 4 & 5 & 6 \\
\hline & $\Delta$ cash comp & $\Delta$ equity comp & $\Delta$ total comp & $\Delta$ cash comp & $\Delta$ equity comp & $\Delta$ total comp \\
\hline \multirow[t]{2}{*}{ Constant } & 3.854 & 5.297 & -48.976 & -4.785 & 16.856 & 60.031 \\
\hline & $(1.573)$ & $(1.232)$ & $(-0.964)$ & $(0.521)$ & $(1.590)$ & $(0.721)$ \\
\hline \multirow[t]{2}{*}{ Change of MV } & $0.076^{*}$ & $0.036 * *$ & $0.069 * *$ & 0.101 & 0.049 & 0.052 \\
\hline & $(2.269)$ & $(2.772)$ & $(2.279)$ & $(0.935)$ & $(0.427)$ & $(0.319)$ \\
\hline \multirow[t]{2}{*}{ Firm size } & $0.116^{* * *}$ & 0.058 & 0.071 & 0.010 & 0.435 & -0.139 \\
\hline & $(2.739)$ & $(0.780)$ & $(1.327)$ & $(0.137)$ & $(1.374)$ & $(-0.748)$ \\
\hline \multirow[t]{2}{*}{ Free cash } & 0.048 & 0.579 & -0.040 & 0.027 & 0.115 & 0.253 \\
\hline & $(0.702)$ & $(0.833)$ & $(-0.474)$ & $(0.172)$ & $(0.369)$ & $(0.395)$ \\
\hline \multirow[t]{2}{*}{ Risk } & 0.164 & 0.248 & 0.875 & $0.148 * *$ & 0.753 & 0.548 \\
\hline & $(0.937)$ & $(1.037)$ & $(0.846)$ & $(2.843)$ & $(0.408)$ & $(0.478)$ \\
\hline \multirow[t]{2}{*}{ Invest. Opp. } & 0.018 & $-0.674 * * *$ & $-0.248 * *$ & 0.015 & 0.047 & 0.033 \\
\hline & $(0.135)$ & $(-3.057)$ & $(-2.821)$ & $(0.209)$ & $(0.924)$ & $(0.450)$ \\
\hline \multirow[t]{2}{*}{ Expense } & 0.156 & 0.093 & 0.136 & 0.012 & -0.034 & -0.121 \\
\hline & (1.084) & (1.113) & $(0.587)$ & (0.109) & $(-0.932)$ & $(0.624)$ \\
\hline \multirow[t]{2}{*}{ Dividend } & $-0.130 * * *$ & 0.032 & 0.083 & 0.135 & 0.158 & 0.015 \\
\hline & (2.912) & $(0.747)$ & $(0.846)$ & $(0.389)$ & $(0.739)$ & $(0.260)$ \\
\hline \multirow[t]{2}{*}{ Leverage } & $-0.145^{*}$ & -0.074 & -0.014 & -0.226 & -0.174 & -0.062 \\
\hline & $(-1.957)$ & $(-0.885)$ & $(-0.632)$ & $(-0.271)$ & $(-0.839)$ & $(-0.557)$ \\
\hline \multirow[t]{2}{*}{ Tobin's Q } & -0.167 & 0.019 & 0.016 & -0.195 & 0.325 & 0.026 \\
\hline & $(-0.392)$ & $(-0.123)$ & $(0.276)$ & $(-0.645)$ & $(0.176)$ & $(0.178)$ \\
\hline \multirow[t]{2}{*}{ ROA } & -0.340 & 0.033 & 0.124 & 0.342 & 0.105 & 0.357 \\
\hline & $(-0.498)$ & $(0.925)$ & $(0.560)$ & $(0.483)$ & $(0.265)$ & $(1.252)$ \\
\hline F-statistics & $2.660 * *$ & $5.217 * * *$ & $12.190 * * *$ & $2.534 * * *$ & 0.681 & 0.877 \\
\hline $\begin{array}{l}\text { Adjusted R } \\
\text { square }\end{array}$ & $2.3 \%$ & $12.9 \%$ & $11.2 \%$ & $2.9 \%$ & $-6.7 \%$ & $-4.1 \%$ \\
\hline
\end{tabular}

$\Delta$ cash comp is annual change of cash compensation. $\Delta$ equity comp is annual change of equity compensation. $\Delta$ total comp is annual change of total compensation. Change of MV is annual change of market value. ***, **, and * denote significance level of $1 \%, 5 \%$, and $10 \%$. T-statistics are in parentheses.

The first three regressions in Table 7 test pay-performance sensitivity of director compensation in Delaware firms. Cash compensation includes an annual retainer and total meeting fees. In the first regression, the estimated coefficient of the change of market value is 0.076 and significant at $10 \%$ for Delaware firms. Therefore, the change of director cash compensation is positively and significantly related to the change of the market value. However, the estimated coefficient of the change of market value in the fourth regression is insignificant for non-Delaware firms, indicating that the change of director cash compensation is not related to the change of the market value.

The second regression tests pay-performance sensitivity of director equity compensation in Delaware firms. The estimated coefficient of change of market value is 0.036 and significant at $5 \%$ for Delaware firms. However, the estimated coefficient of change of market value in the fifth regression is insignificant for non-Delaware firms again.

Total director compensation includes an annual retainer, meeting fees, stocks, options, and the others. The estimated coefficient of the change of market value is 0.069 and significant at $5 \%$ for Delaware firms in the third regression but not for non-Delaware firms in the sixth regression. 


\section{Conclusion}

The question of whether Delaware incorporation favors shareholders is an on-going debate. If Delaware incorporation indeed favors shareholders, directors in Delaware firms are more likely to be encouraged to monitor CEOs.

This study is conducted by using a sample of 628 Delaware firms and 423 non-Delaware firms in Execucomp from 2002 to 2009. A firm incorporated in Delaware generally pays its directors more annual retainer, cash compensation, stock compensation, option compensation, equity compensation, and total compensation than a non-Delaware firm does. In addition, a Delaware firm tends to hold more meetings per year than a non-Delaware firm does. Most importantly, among Delaware firms, director compensation is positively related to shareholder wealth. All the findings indicate that Delaware incorporation appears to financially encourage the board to perform its monitoring role. This paper is the first attempt to examine director compensation by considering the role of state of incorporation. The findings indicate that the view of "race to the top" (Winter, 1977) is supported. The findings also imply that external corporate governance mechanism, state corporate laws, does interact with and even influence internal monitoring mechanism, the Board of Directors, to minimize agency problem among publicly traded companies. Delaware incorporation sends positive signals to shareholders in a firm that must choose a state to incorporate or reincorporate.

\section{References}

Adams, R.B., \& Ferreira, D. (2008). Do directors perform for pay? Journal of Accounting and Economics, 46(1), 154-171. http://dx.doi.org/10.1016/j.jacceco.2008.06.002

Bebchuk, L., \& Ferrell, A. (2001). A new approach to takeover law and regulatory competition. Virginia Law Review, 87(1), 111-164. http://dx.doi.org/10.2307/1073896

Bebchuk, L., Fried, J., \& Walker, D. (2002). Managerial power and rent extraction in the design of executive compensation. University of Chicago Law Review, 69(3), 751-761. http://dx.doi.org/10.2307/1600632

Becher, D. A., Campbell, T., \& Varma, R. (2004). The effect of Delaware law on firm value: evidence from poison pill adoptions. Working paper. Drexel University and University of Delaware.

Becher, D.A., Campbell, T.L., \& Frye, M.B. (2005). Incentive compensation for bank directors: The impact of deregulation. The Journal of Business, 78(5), 1753-1778. http://dx.doi.org/10.1086/431441

Benito, A., \& Conyon, M. J. (1999). The governance of directors' pay: evidence from UK companies. Journal of Management and Governance, 3(2), 117-136. http://dx.doi.org/10.1023/A:1009995710541

Black, B. (1990). Is corporate law trivial? A political and economic analysis. Northwestern Law Review, 84, 542-597.

Borokhovich, K.A., Parrino, R., \& Trapani, T. (1996). Outside Directors and CEO Selection. Journal of Financial and Quantitative Analysis, 31, 337-355. http://dx.doi.org/10.2307/2331395

Brick, E., Palmon, O., \& Wald, J. (2006). CEO compensation, director compensation, and firm performance: evidence of Cronyism. Journal of Corporate Finance, 12(3), 403-423. http://dx.doi.org/10.1016/j.jcorpfin.2005.08.005

Brickley, J., Coles, L., \& Terry, R. (1994). Outside directors and the adoption of poison pills. Journal of Financial Economics, 34(3), 371-390. http://dx.doi.org/10.1016/0304-405X(94)90038-8

Byrd, J., \& Hickman, A. (1992). Do outside directors monitor managers? Evidence from tender offer bids. Journal of Financial Economics, 32(4), 195-221. http://dx.doi.org/10.1016/0304-405X(92)90018-S

Cary, W. (1974). Federalism and corporate law: reflections upon Delaware. Yale Law Journal, 83(4), 663-705. http://dx.doi.org/10.2307/795524

Choi, D., Kamma, S., \& Weintrop, J. (1989). The Delaware Courts, Poison Pills, and Shareholder Wealth. Journal of Law, Economics, and organization, 5(2), 375-394

Clark, R. (1985). Agency costs versus fiduciary duties, in John Pratt and Richard Zeckhauser, Eds.: Principals and Agents: The Structure of Business. Harvard Business School Press, Cambridge, Mass.

Cotter, J., Shivdasani, A., \& Zenner, M. (1997). Do independent directors enhance target shareholder wealth during tender offers? Economics, 43(2), 195-218.

Daines, R. (2001). Does Delaware law improve firm value? Journal of Financial Economics, 62(3), 525-558. http://dx.doi.org/10.1016/S0304-405X(01)00086-1

Fama, E., \& French, K. (2002). Testing trade-off and packing order predictions about dividends and debt. The Review of Financial Studies, 15(1), 1-33. http://dx.doi.org/10.1093/rfs/15.1.1 
Fich, E. M., \& Shivdasani, A. (2005). The impact of stock-option compensation for outside directors on firm value. Journal of Business, 78(6), 2229-2254. http://dx.doi.org/10.1086/497048

Fich, E. M., \& Shivdasani, A. (2006). Are busy boards effective monitors? Journal of Finance, 61(2), 689-724. http://dx.doi.org/10.1111/j.1540-6261.2006.00852.x

Gillette, A. B., Noe, T. H., \& Rebello, M. J. (2003). Corporate board composition, protocols, and voting behavior: experimental evidence. Journal of Finance, 58(5), 1997-2032. http://dx.doi.org/10.1111/1540-6261.00595

Gompers, P., Ishii, J., \& Metrick, A. (2003). Corporate governance and equity prices. Quarterly Journal of Economics, 118(1), 107-155. http://dx.doi.org/10.1162/00335530360535162

Hermalin, B., \& Weisbach, M. (1998). Endogenously chosen boards of directors and their monitoring of the CEO. American Economic Review, 88(1), 96-118.

Jagannathan, M., Paul, S., \& Pritchard, A.C. (2007). Does Delaware entrench management? Working paper. Binghamton University and University of Michigan Law School.

Jensen, M. (1986). Agency costs of free cash flow, corporate finance, and takeovers. American Economic Review, 76(2), 323-329.

Jensen, M., \& Murphy, K. (1990a). Performance Pay and Top-management Incentives. The Journal of Political Economy, 98(2), 225-264. http://dx.doi.org/10.1086/261677

Jensen, M., \& Murphy, K. (1990b). CEO Incentives-It's Not How Much You Pay, but How. Harvard Business Review, 68(3), 138-149.

Jiraporn, P., \& Gleason, K. C. (2007). Delaware incorporation and earnings management: an empirical analysis. Journal of Applied Finance, 17(1), 40-51.

Jiraporn, P., Chintrakarn, P., \& Davidson, W. (2009). Delaware Incorporation and the Board of Directors. Quarterly Journal of Finance \& Accounting, 48(3), 41-59.

John, K., \& Senbet, L. W. (1998). Corporate governance and board effectiveness. Journal of Finance, 48(3), 949-974. http://dx.doi.org/10.1111/j.1540-6261.1993.tb04026.x

Lipton, M., \& Lorsch, J. (1992). A modest proposal for improved corporate governance. Business Lawyer, 48, 59-77.

Murphy, K. J., \& Zabojnik, J. (2004). CEO pay and appointments: a market-based explanation for recent trends. American Economic Review, 94(2), 192-196. http://dx.doi.org/10.1257/0002828041302262

Perfect, S. B., \& Wiles, K. W. (1994). Alternative constructions of Tobin's q: An empirical comparison. Journal of Empirical Finance, 1(3), 313-341. http://dx.doi.org/10.1016/0927-5398(94)90007-8

Perry, T. (2000). Incentive compensation for outside directors and CEO turnover. Working paper. Arizona State University.

Spatt, C. S. (2005, June 9). Speech by SEC staff: governance, the board and compensation. Retrieved from http://www.sec.gov/news/speech/spch060905css.htm

Subramanian, G. (2002). The influence of antitakeover statutes on incorporation choice: evidence on the "race" debate and antitakeover overreaching. University of Pennsylvania Law Review, 150(6), 1795-1873. http://dx.doi.org/10.2307/3312981

Subramanian, G. (2004). The disappearing Delaware Effect. Journal of Law, Economics, and Organization, 20(1), 32-59. http://dx.doi.org/10.1093/jleo/ewh023

Vafeas, N. (1999). Bard meeting frequency and firm performance. Journal of Financial Economics, 53, $113-142$. http://dx.doi.org/10.1016/S0304-405X(99)00018-5

Weisbach, M. (1988). Outside directors and CEO turnover. Journal of Financial Economic, 20(1/2), 431-460. http://dx.doi.org/10.1016/0304-405X(88)90053-0

Winter, R. K. (1977). State law, shareholder protection, and the theory of the corporation. Journal of Legal Studies, 6(2), 251-292. http://dx.doi.org/10.1086/467572

Yermack, D. (1996). Higher market valuation for firms with small board of directors. Journal of Financial Economics, 40(20), 185-21. http://dx.doi.org/10.1016/0304-405X(95)00844-5

Yermack, D. (2004). Remuneration, Retention, and Reputation Incentives for Outside Directors. Journal of Finance, 59(5), 2281-2308. http://dx.doi.org/10.1111/j.1540-6261.2004.00699.x 